
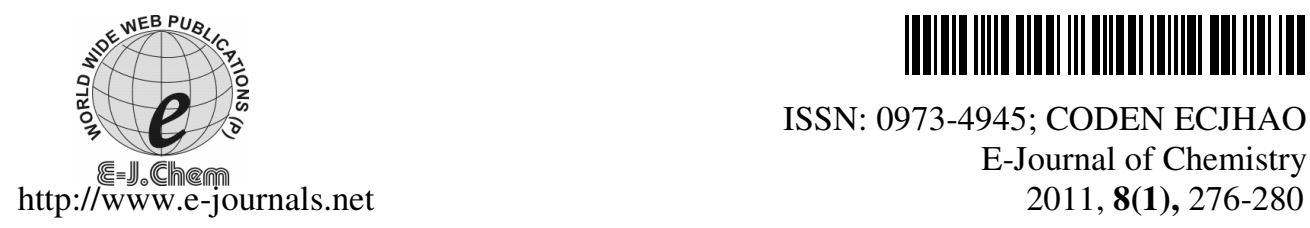

ISSN: 0973-4945; CODEN ECJHAO

E-Journal of Chemistry

$2011,8(\mathbf{1}), 276-280$

\title{
Assessment of Some Heavy Metals in Drinking Water Samples of Tunceli, Turkey
}

\author{
OLCAY KAPLAN, NURAN CIKCIKOGLU YILDIRIM*, \\ NUMAN YILDIRIM and NILGUN TAYHAN
}

Tunceli University, Faculty of Engineering Department of Food Engineering, 62000, Tunceli, Turkey

*Tunceli University, Faculty of Engineering Department of Environmental Engineering, 62000, Tunceli, Turkey

nurancyildirim@tunceli.edu.tr

Received 10 May 2010; Accepted 20 July 2010

\begin{abstract}
The drinking water quality is associated with the conditions of the water supply networks, the pollution and the contamination of groundwater with pollutants of both anthropogenic and natural origin. In this study, water samples were taken from four different waterworks in Tunceli, Turkey and heavy metals concentrations ( $\mathrm{As}, \mathrm{Cu}, \mathrm{Cd}, \mathrm{Cr}, \mathrm{Pb}, \mathrm{Ni}$ and $\mathrm{Hg}$ ) were measured. Four sampling sites were pre-defined in different locations of the city. The obtained results showed that, the heavy metals concentrations in water samples did not exceed the values of WHO (World Health Organization), EC (Europe Community), EPA (Environment Protection Agency) and TSE-266 (Turkish Standard) guidelines.
\end{abstract}

Keywords: Heavy metal, Drinking water, Health, Turkey.

\section{Introduction}

Safe and good quality drinking water is the basis for good human health. Water provides some elements, but when polluted it may become the source of undesirable substances dangerous to human health and cause disease such as, various cancers, adverse reproductive outcomes, cardiovascular disease and neurological disease ${ }^{1-4}$. Therefore the heavy metal concentration in drinking water should be kept in the low ppb range.

One of the most hazardous trace metals found in drinking waters is arsenic (As) being both toxic and carcinogenic. Long term intake of arsenic may give rise to skin lesions ${ }^{5}$ at concentrations $50 \mathrm{mg} \mathrm{L}^{-1}$. Cadmium $(\mathrm{Cd})$ and lead $(\mathrm{Pb})$ are the heavy metals more critical for the human health, also ${ }^{6,7}$. Cd may be cause the diseases; hypertension, arteriosclerosis, cancer, etc $^{8,9}$. The World Health Organization (WHO) established as $3 \mu \mathrm{g} \mathrm{L}^{-1}$ and Environmental 
Protection Agency (EPA) established $5 \mu \mathrm{g} \mathrm{L}^{-1}$ the maximum permissible for $\mathrm{Cd}^{8,10}$ and WHO has established maximum allowable limits for $\mathrm{Pb} 10 \mu \mathrm{g} \mathrm{L}^{-1}$ for drinking waters ${ }^{11}$. Chromium $(\mathrm{Cr})$ is an essential trace metal in both human and animals but excessive amounts of chromium, particularly in the more toxic $\mathrm{Cr}(\mathrm{VI})$ valence state, are detrimental to health as it may be involved in the pathogenesis of some diseases such as lung and gastrointestinal cancer $^{12}$. Elevated copper $(\mathrm{Cu})$ level in drinking water may have a neurotoxic potential and can produce mental diseases such as Alzheimer's ${ }^{13}$.

Although concentrations of some heavy metals have been measured in tap, surface and other water samples in Turkey ${ }^{14-18}$, but the consumed waters in Tunceli have not been investigated. The water demand in Tunceli is supplied by underground waters. A measurement of the concentration of heavy metals in different water supplies in Tunceli/or in other city is extremely important for proper assessment of the hazards associated with their intake.

In this study, water samples were taken in Tunceli from four different waterworks. The goals of the present study were to investigate concentrations of $\mathrm{As}, \mathrm{Cu}, \mathrm{Cd}, \mathrm{Cr}, \mathrm{Pb}, \mathrm{Ni}$ and $\mathrm{Hg}$ in Tunceli's drinking water, to identify contamination sources and processes and to ascertain whether metals in household drinking water in Tunceli a risk to public health.

\section{Experimental}

Most samples were taken in October 2009. All data sets were obtained from the Health Directorate of Tunceli in order to estimate the exposure and risk levels for Tunceli population associated with ingestion of metals in drinking water. The water samples were acidified prior to analysis by addition of $1 \%(\mathrm{v} / \mathrm{v})$ of nitric acid. All samples were kept in $1000 \mathrm{~mL}$ polypropylene bottles and stored at $+4{ }^{\circ} \mathrm{C}$ until analyses. The sampling stations were shown in Figure 1 and Table 1.

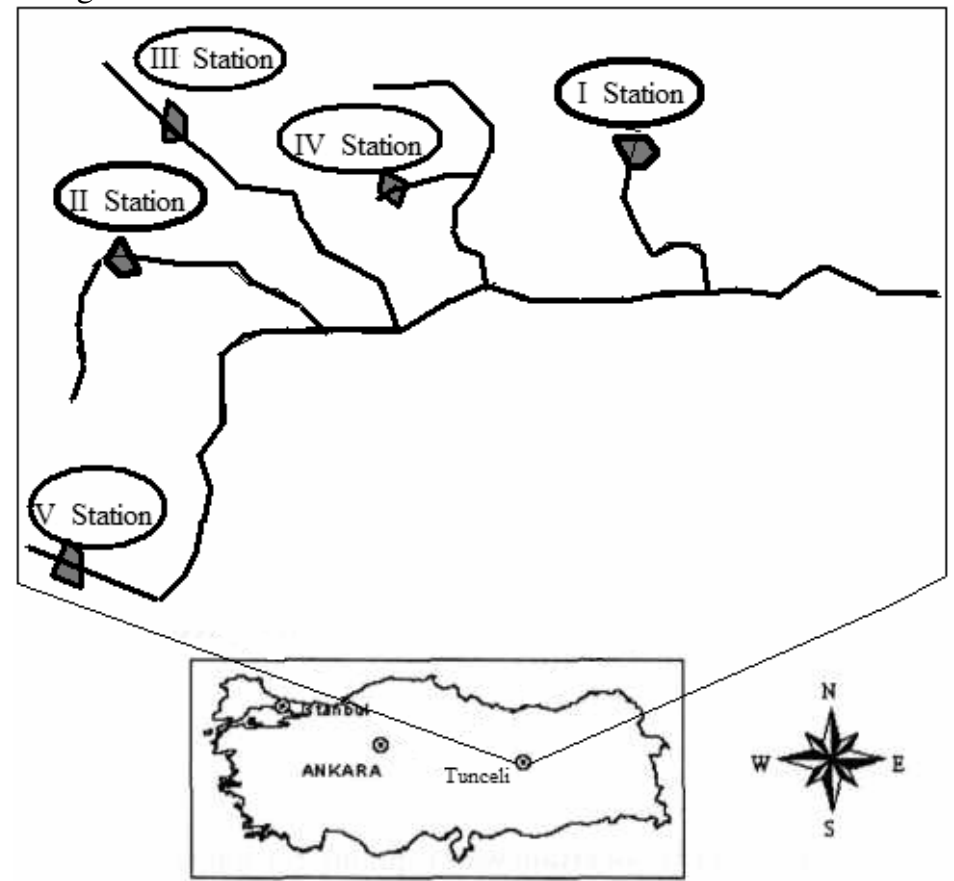

Figure 1. Map of the sampling stations. 
Table 1. List of the sampling stations

\begin{tabular}{cc}
\hline Station no & Station name \\
\hline I & Esentepe quarter water reservoir \\
II & Esentepe quarter water supply \\
III & Cumhuriyet quarter drilling water \\
IV & Alibaba quarter water supply \\
V & Atatürk quarter water supply \\
\hline
\end{tabular}

\section{Analysis of metals}

The concentrations of elements $(\mathrm{Cu}, \mathrm{Pb}, \mathrm{Ni}, \mathrm{As}, \mathrm{Cd}$ and $\mathrm{Cr})$ were measured using graphite furnace atomic absorption (GFAAS) spectrophotometer. $\mathrm{Hg}$ concentration in prepared sample was measured using atomic absorption spectrophotometer (AAS).

\section{Statistical treatment}

The data were analyzed using statistical software program (SPSS 12.0 for Windows). Data were compared using one-way analysis of variance. Results were expressed as mean \pm SD for the three experiments.

\section{Results and Discussion}

The heavy metal content of the drinking water samples including $\mathrm{As}, \mathrm{Cu}, \mathrm{Cd}, \mathrm{Cr}, \mathrm{Pb}, \mathrm{Ni}$ and $\mathrm{Hg}$ from Tunceli-Turkey were given in Table 2. Cadmium in the investigated water samples were found in the range of $<0.05-1.67 \mu \mathrm{g} \mathrm{L}^{-1}$. Cd concentrations in unpolluted natural waters are usually ${ }^{19}$ below $1 \mu \mathrm{g} \mathrm{L}^{-1}$. Median concentrations of dissolved cadmium measured at 110 stations around the world were $<1 \mu \mathrm{g} \mathrm{L} \mathrm{L}^{-1}$, the maximum value recorded being $100 \mu \mathrm{g} \mathrm{L}^{-1}$ in the Rio Rimao in Peru ${ }^{20}$. Contamination of drinking water may occur as a result of the presence of cadmium as an impurity in the zinc of galvanized pipes or cadmium containing solders in fittings, water heaters, water coolers and taps ${ }^{19}$. Mercury levels were detected below $0.02 \mu \mathrm{g} \mathrm{L}^{-1}$ at all stations. It was reported that the concentration range for $\mathrm{Hg}$ in drinking water was the same as in rain, with an average of about ${ }^{21} 25 \mathrm{ng} \mathrm{L}^{-1}$. It was determined that $\mathrm{Hg}$ concentrations in investigated water were below this level. The WHO provisional guideline of $10 \mu \mathrm{g} \mathrm{L}^{-1}$ for As has been adopted as a national standard by most countries and by the European Union (EU). In our study, As content of the samples were in the range of $<0.5-2.02 \mu \mathrm{g} \mathrm{L}^{-1}$. It was determined that as level measured in this study was under $10 \mu \mathrm{g} \mathrm{L}^{-1}$. The ranges for nickel (Ni) were $<0.6$ to $2.21 \mu \mathrm{g} \mathrm{L}^{-1}$ (Table 2). In Canada, the median Ni level in drinking water supplies was below $2 \mu \mathrm{g} \mathrm{L}^{-1}$, the maximum level observed ${ }^{22}$ was $69 \mu \mathrm{g} \mathrm{L}^{-1}$.

Table 2. Heavy metal content of the drinking water samples from Tunceli, Turkey

\begin{tabular}{ccccccccc}
\hline \multicolumn{7}{c}{ Elements ${ }^{*}, \mu \mathrm{g} \mathrm{L}^{-1}$} \\
$\begin{array}{c}\text { Station } \\
\text { no }\end{array}$ & $\mathrm{As}$ & $\mathrm{Cu}$ & $\mathrm{Cd}$ & $\mathrm{Cr}$ & $\mathrm{Pb}$ & $\mathrm{Ni}$ & $\mathrm{Hg}$ \\
\hline I & $2.02 \pm 0.92$ & $0.40 \pm 0.01$ & $1.27 \pm 0.04$ & $0.30 \pm 0.03$ & $\mathrm{BDL}^{* *}$ & $0.88 \pm 0.04$ & $<0.02$ \\
II & $1.20 \pm 0.01$ & $0.38 \pm 0.02$ & $<0.05$ & $3.99 \pm 0.56$ & $0.31 \pm 0.02$ & $1.73 \pm 0.46$ & $<0.02$ \\
III & $<0.5$ & $<0.05$ & $<0.05$ & $<0.1$ & $\mathrm{BDL}$ & $<0.6$ & $<0.02$ \\
IV & $1.22 \pm 0.01$ & $0.32 \pm 0.02$ & $1.67 \pm 0.04$ & $3.50 \pm 0.45$ & $\mathrm{BDL}$ & $2.21 \pm 1.03$ & $<0.02$ \\
V & $0.98 \pm 0.03$ & $<0.05$ & $<0.05$ & $<0.1$ & $\mathrm{BDL}$ & $<0.6$ & $<0.02$ \\
\hline \multicolumn{7}{c}{ Means $\pm S D, n=3, B D L^{* *}=$ Below Detection Limit } \\
\end{tabular}


The copper content of the samples were in the range of $<0.05-0.40 \mu \mathrm{g} \mathrm{L}^{-1}$. The highest values $\left(0.40 \mu \mathrm{g} \mathrm{L}^{-1}\right)$ were in Esentepe quarter water reservoir. $\mathrm{Cu}$ was considerably below the limit of $1.0 \mathrm{mg} \mathrm{L}^{-1}$ permitted by WHO in drinking waters ${ }^{23}$. It was reported that $\mathrm{Cu}$ concentrations of drinking water samples from Northern Mexico as 0.1-319 $\mu \mathrm{g} \mathrm{L}^{-124}$. Manzoori and Bavili-Tabrizi ${ }^{25}$ have reported that $\mathrm{Cu}$ concentration in water from Tabriz City, Iran, as $32 \mu \mathrm{g} \mathrm{L}^{-1}$. Consequently, no contamination due to copper exists in the drinking water samples from Tunceli. The levels of lead in the samples (I, III, IV and V stations) were BDL (Below Detection Limit). The highest values $\left(0.31 \mu \mathrm{g} \mathrm{L}^{-1}\right)$ were in Esentepe quarter water supply. The action level for $\mathrm{Pb}$ recommended by EPA is $15 \mu \mathrm{g} \mathrm{L}^{-1}$. The lead levels in all stations were below this level (Table 2). A major source of environmental $\mathrm{Pb}$, particularly in urban areas, is due to the combustion of leaded petrol. Lead is discharged by vehicles into air, then adsorbed from the air by environmental samples such as soil and plants $^{26,27}$. Lead then enters the waterways from soil, thus affecting the levels of lead in natural waters. The chromium content of the samples was in the range of $<0.1-3.99 \mu \mathrm{g} \mathrm{L}^{-1}$. The Office of Environmental Health Hazard Assessment (OEHHA) ${ }^{28}$ has developed a Public Health Goal (PHG) of $2.5 \times 10^{-3} \mathrm{mg} \mathrm{L}^{-1}$ for total $\mathrm{Cr}$. In this study $\mathrm{Cr}$ concentrations were found under this level.

\section{Conclusion}

The concentrations of the investigated heavy metals ( $\mathrm{As}, \mathrm{Cu}, \mathrm{Cd}, \mathrm{Cr}, \mathrm{Pb}, \mathrm{Ni}$ and $\mathrm{Hg}$ ) in the drinking water samples from Tunceli/Turkey were found below the guidelines for drinking waters given by the WHO and the Water Pollution Control Regulation of Turkish Authorities. It was concluded that drinking waters in Tunceli contain low heavy metal levels. Because, there is no industrial zone in and around Tunceli city.

\section{Acknowledgment}

We are thankful to Yılmaz Arıcı for his suggestions and cooperation.

\section{References}

1. Karavoltsos S, Sakellari A, Mihopoulos N, Dassenakis M and Scoullos M J, Desalination, 2008, 224(1-3), 317-329.

2. Calderon R L, Food Chem Toxicol., 2000, 38(1), S13-S20.

3. Xia Y and Liu J, Toxicol., 2004, 198, 25-29.

4. Dogan M, Dogan A U, Celebi C and Baris Y I, Indoor Built Environ., 2005, 14(6), 533-536.

5. World Health Organization (WHO), Environmental Health Criteria 224: Arsenic and Arsenic Compounds, second ed. World Health Organiza- tion, Geneva, 2001.

6. Davis A C, Wu P, Zhang X F, Hou X D and Jones B T, Appl Spectrosc Rev., 2006, 41(1), 35-75.

7. Kaplan O and Yaman M, Atomic Spectroscopy, 2009, 30(1), 1-9.

8. World Health Organization (WHO), Guidelines for Drinking Water Quality, Health Criteria and Other Supporting Information, vol. 2, $2^{\text {nd }}$ Ed., World Health Organization, Geneva, 1998.

9. Bertin G and Averbeck D, Biochimie, 2006, 88(11), 1549-1559.

10. Environmental Protection Agency (EPA), Edition of the drinking water standards and health advisories, EPA 822-R-02-38, Washington, DC, 2002.

11. World Health Organization (WHO), Guidelines for drinking water quality, Health Criteria and Other Supporting Information, vol. 2, $2^{\text {nd }}$ Ed., WHO, p. 973, Geneva, 1996. 
12. Burguera J L, Burguera $\mathrm{M}$, Rondon $\mathrm{C}$, Rodriguez L, Carrero $\mathrm{P}$, Petit de Peña and Burguera E, J Anal At Spectrom., 1999, 14, 821-825.

13. Dieter H H, Bayer T A and Multhaup G, Acta Hydrochimica et Hydrobiologica, 2005, 33(1), 72-78.

14. Ongen A, Dokmeci H, Celik S O, Sabudak T, Kaykioglu G and Dokmeci I, J Environ Protection Ecology, 2008, 9(4), 753-762.

15. Oner F, Yalim H A, Akkurt A and Orbay M, Radiation Protection Dosimetry 2009, 133(4), 223-226.

16. Tanir F, Goksu M Z L and Akbaba M, Asian J Chem., 2005, 17(4), 2443-2450.

17. Baba A and Gunduz O, Progress in Environ Sci Technol., 2009, 2, 620-622.

18. Ince M, kaplan O and Yaman M, Water Environ Res., 2008, 80(11), 2104-2110.

19. Friberg L, Nordberg G F and Vouk V B, Eds.,Handbook of the toxicology of metals. Amsterdam, Elsevier, 1986, 2,130-184.

20. WHO/UNEP GEMS-Global fresh water quality. Published on behalf of the World Health Organization/United Nations Environment Programme. Oxford, Blackwell Reference 1989.

21. IPCS Methylmercury. World Health Organization, International Programme on Chemical Safety (Environmental Health Criteria 101), Geneva, 1990.

22. Meranger J C, Subramanian K S and Chalifoux C, J Associ Offic Anal Chem., 1981, 64, 44-53.

23. World Health Organization (WHO) Guidelines for Drinking Water Quality $\left(2^{\text {nd }}\right.$ Ed.,) Recommendations, Geneva, 1993, Vol. 1-2.

24. Wyatt C J, Fimbre C, Ro Mo L, Mendez R O and Grijalva M, Environ Res., 1998, 76(2)A, 114-119.

25. Manzoori J L and Bavili-Tabrizi A, Microchem J., 2002, 72(1), 1-7.

26. Asubiojo O I, Nkono N A, Ogunsua O A, Oluwole A F, Ward N I, Akanle O A and Spyrou N M, Sci Total Environ., 1997, 208(1-2), 1-8.

27. Soylak M and Elci L, J Trace Microprobe Technol., 2000, 18, 397-403.

28. OEHHA Carcinogenicity of chromium VI via ingestion. Memo from Richard J. Jackson to Steven A, Book. June 11, 1991. 


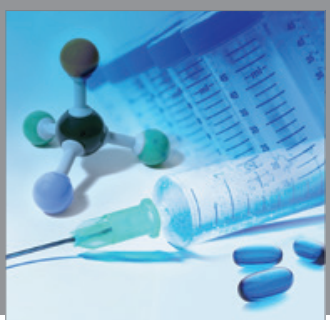

International Journal of

Medicinal Chemistry

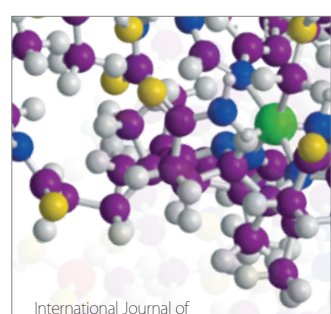

Carbohydrate Chemistry

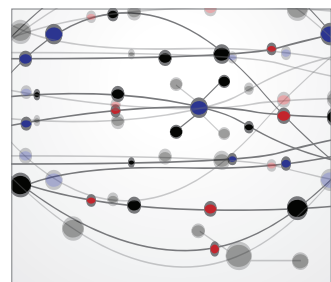

The Scientific World Journal
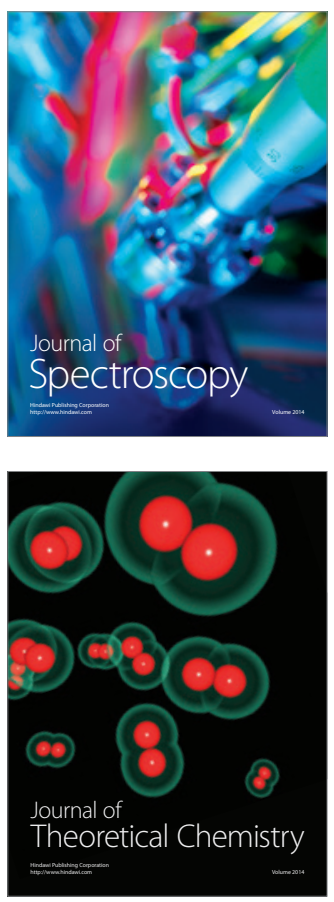
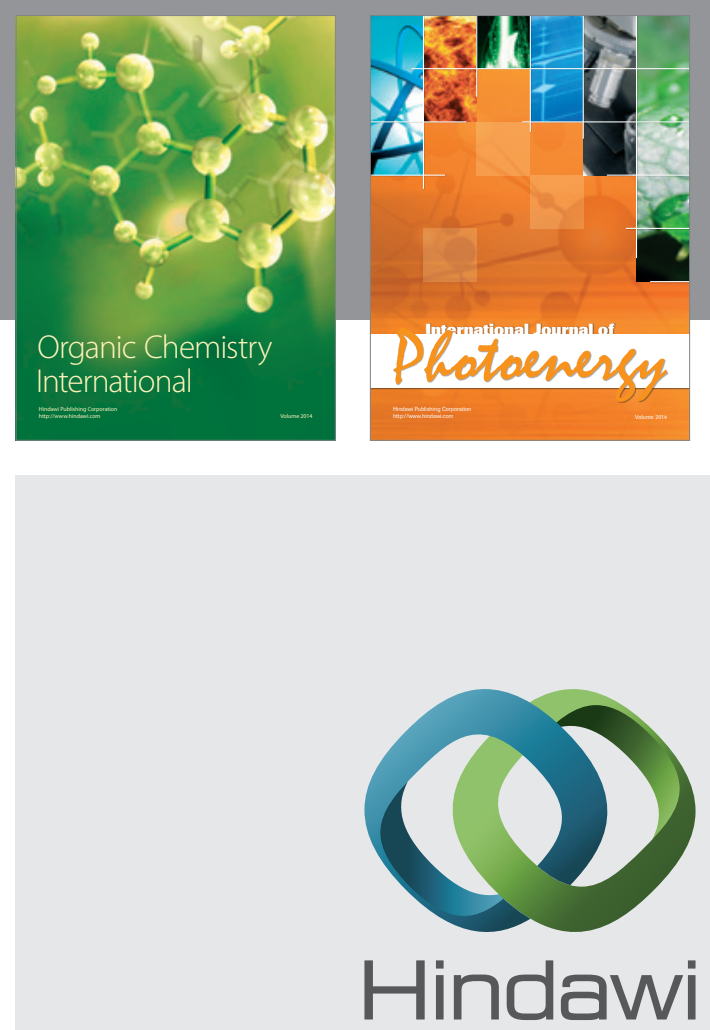

Submit your manuscripts at

http://www.hindawi.com
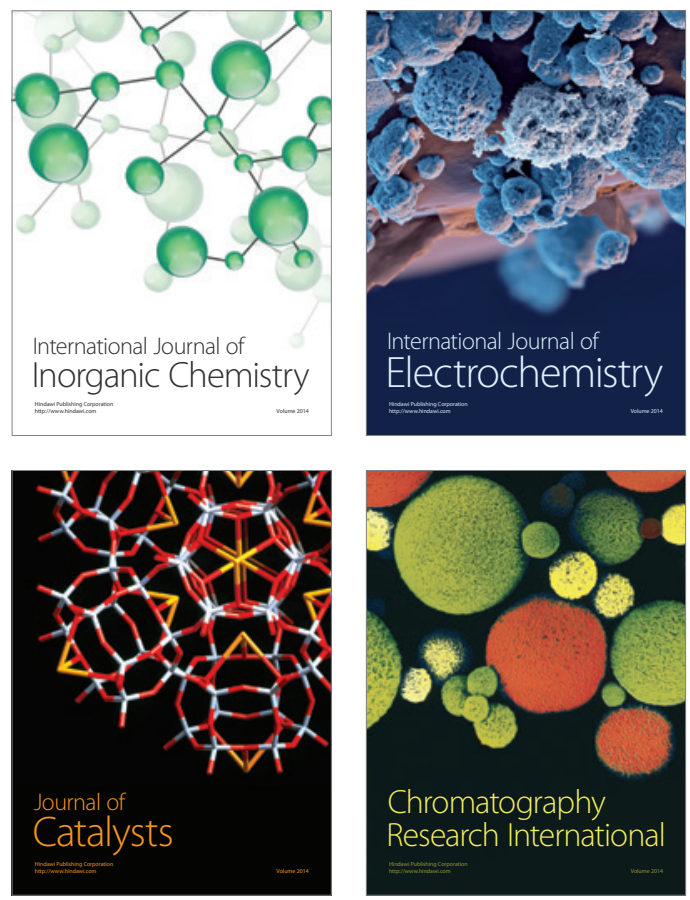
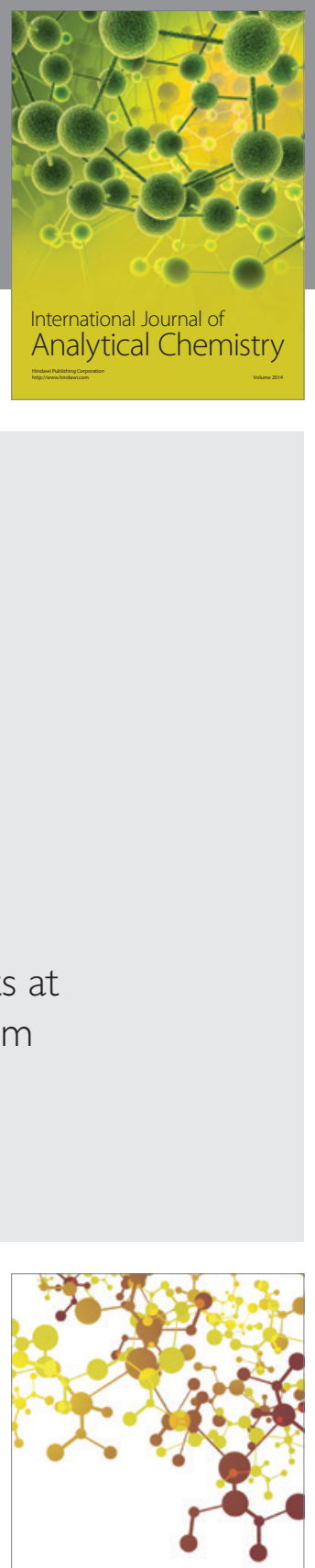

Journal of

Applied Chemistry
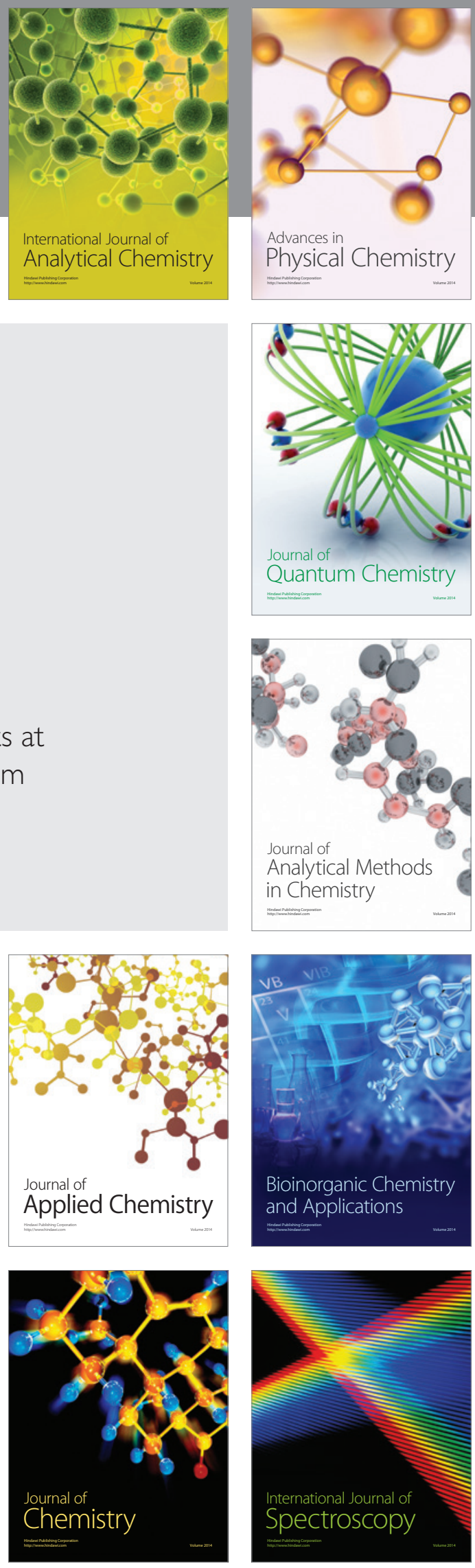